\title{
Making the most of an early start to L2 instruction
}

\author{
Simone E. Pfenninger and David Singleton \\ University of Salzburg Trinity College Dublin
}

\begin{abstract}
Research over more than forty years has shown consistently that earlier L2 starters do not in the long term maintain the linguistic advantage of an early start over older starters. What, then, in the light of the widespread setting aside of the evidence regarding the apparent uselessness of an early start, is one to advise in respect of early L2 instruction? In this paper we discuss four factors which emerge as perhaps having relevance in this regard: the role of (bi)literacy skills, the role of language learning motivation, the role of factors relating to the transition from primary to secondary school, and the role of intensity of $\mathrm{L}_{2}$ instruction. We suggest that there are a number of broader macro-institutional factors, such as the impact of classroom experiences, that may impede the goal sought by the offering of numerous years of continued FL instruction.
\end{abstract}

Keywords: age factor, young learners, intensity, L2 motivation, literacy, bilingual advantage

The question of starting age for additional languages in school is an important and controversial one. Because of the popular view that "younger = better", which is supported by a general trend in research dealing with non-instructed L2 acquisition, the tendency has been for governments and education planners to take the line that an earlier introduction of L2s into schools will be advantageous. Yet research over more than forty years has shown consistently that earlier L2 starters do not in the long term maintain the linguistic advantage of an early start over older starters (see Muñoz \& Singleton, 2011). Indeed, in a recent study (Pfenninger \& Singleton, 2017), older beginners were found to catch up in most respects with younger beginners within six months - despite a five-year exposure advantage on the part of these latter. The educational world has largely ignored such findings and has increasingly established the primary school teaching of L2s as the norm. 
What, then, in the light of the widespread setting aside of the evidence regarding the apparent uselessness of an early start, is one to advise in respect of early L2 instruction? Some possible areas other than maturation (see Pica, 2011) may be relevant to possible benefits accruing from encountering additional languages in the primary school. In what follows we discuss four factors which emerge as perhaps having relevance in this regard: the role of (bi)literacy skills, the role of language learning motivation, the role of factors relating to the transition from primary to secondary school, and the role of intensity of L2 instruction.

\section{Literacy skills, previous languages and interdependence}

It is widely believed that the most important factor in mastering a foreign language is achievement in the first language (see e.g., Truniger, 1998). Linguists' engagement with the issues of bilingualism, literacy skills and additional L2 learning has gradually developed from deficit views to a resource-oriented view. While the deficit-oriented views focused on the difficulties encountered by multilingual children, resource-oriented views emphasize the possibilities that multilingualism enables (Berthele \& Lambelet, 2017a). In particular, this positive view points to the potential of transfer of aspects of language as well as of strategies of language learning and use. Cummins (1979, 2000) also hypothesized in his 'Developmental Interdependence Hypothesis' that L1 and L2 literacy skills should be regarded as interdependent - as manifestations of a common underlying proficiency (see also Sparks, 2012).

If text competencies are acquired by an L1-user, and then applied to L2 text, this can be seen as an example of transfer from one language to the other, even though knowledge about how a text is structured, can be considered at least partly language-neutral (Berthele \& Lambelet, 2017b). Geva \& Ryan (1993) suggest that in addition to transfer of linguistic skills from L1 to L2, basic individual differences on various indices of cognitive ability (e.g., nonverbal intelligence, memory) may be at least partially responsible for observed relationships between L1 and L2. They found significant correlations between memory measures and performance on linguistic tasks in L1 and L2 (see also McLaughlin, 199o; Piske, MacKay, \& Flege, 2001; Sparks, Patton, Ganschow, \& Humbach, 2009). Proficiency in languages is expected to be more highly correlated if the languages are similar (Cummins, 2001).

Numerous studies (e.g., Moser, Bayer, \& Tomasik, 2017; Schoonen et al., 2003, 2009, 2011) found a strong relationship between L1 and L2 writing proficiency as well as a relationship between L1 writing and metacognitive knowledge, although the authors were wary of positing causal interpretations. In line with the idea of 
interdependence of different languages in the individual multilingual speakers' repertoires, many researchers rely on correlational studies when making claims about transfer. Perhaps unsurprisingly, applied linguists have recommended heritage language instruction as a means of reducing the 'language gap' between migrant students and non-migrants, especially since, in addition, heritage language knowledge is seen as beneficial for literacy development in the school language (Avineri \& Johnson, 2015).

Although longitudinal designs may be able to model the direction of transfer, it is unclear if positive cross-lagged correlations can be taken as evidence for transfer from language to language, as evidence of the existence of a languageindependent basis of transversal abilities, or even as evidence of the impact of general cognitive development (Berthele \& Lambelet, 2017b). Nor are positive correlations between measurements in two languages sufficient grounds for claims about interdependence; there are simply too many other explanations that are equally compatible with such correlations (see Berthele \& Lambelet, 2017a). Furthermore, the evidence is mixed; some studies have found a negative linear association of L1 and L2 skills. For instance, Nieminen and Ullakonoja's (2017) findings suggest that an early age of onset of learning the L2 (Finnish) in a Finnish environment had a positive impact on mastering the $\mathrm{L}_{2}$ but a negative impact on mastering the L1 (Russian) in writing. By contrast, there are numerous studies that evidence no loss of L1 from early exposure to a new language and no evidence for any effects of heritage language instruction on literacy skills in the school language (e.g., Goorhuis-Brouwer \& de Bot, 2010; Moser et al., 2017; Krompàk, 2017).

Another widespread belief is that the L1 needs to be developed to a certain level in order to guarantee successful cognitive and linguistic development (see e.g., Riehl, 2013) - which Berthele and Lambelet (2017b) refer to as the "first language axiom". Cummins addressed this issue in his 'Threshold Hypothesis' (1976, 1978), suggesting that the L1 competence level already reached by learners determines whether they will experience cognitive deficits or benefits from schooling in the $\mathrm{L}_{2}$ (see Yun, 2005). If the $\mathrm{L}_{1}$ is not sufficiently developed, this will purportedly result in low levels of L2 proficiency (see Martin-Jones \& Romaine, 1986). Lightbown (2000, p. 249) observes that '[i]f the total amount of time of instruction is limited, it is likely to be more effective to begin instruction when learners have reached an age at which they can make use of a variety of learning strategies, including their L1 literacy skills, to make the most of that time.' Jaekel, Schurig, Florian and Ritter (2017) suggest that metalanguage builds rather slowly during the elementary school years in relation to students' L1 for literacy, so that students cannot yet really benefit from a transfer from this process to the L2. The pedagogical implication of this would be to increase L1 instruction, introducing L2 instruction later since it is not crucial at the beginning of literacy development. Other 
scholars suggest that even if L1 literacy is well developed, such knowledge cannot be accessed in L2 if L2 linguistic proficiency is low (see Alderson, 1984; Jeong-Won Lee \& Schallert, 1997). On this view, intensive L2 instruction would be important to exploit the underlying resources.

As for the idea of thresholds: (1) there is no empirical evidence in favour of discontinuous bilingual development (see Vanhove, 2013, 2015); (2) unless thresholds are defined independently, they do not yield predictions that can be proven wrong (Berthele, 2017) - and so the probability of producing false positive results is increased (Vanhove, 2014); and (3) the threshold cannot be defined in absolute terms - i.e. it is impossible to identify a common threshold for all learners. For the purposes of developing educational policies, it would be useful to have a more specific theory on the mechanisms and directions of transfer and interdependence.

In sum, the evidence of L1 effects on L2 proficiency is not overwhelming (Berthele, 2017). Moser et al. (2017) hypothesize that there may be L1-related benefits at least for heritage languages if these languages are used in immersion or CLIL settings. However, the question also arises to what extent L1 experience is helpful for L2 literacy with respect to onset age and length of instruction.

Pfenninger (in press) reported a five-year longitudinal study in Switzerland, in which the English development of 636 secondary school students was assessed; all had learned Standard German and French at primary school, but only half had had English from third grade (age 8) onwards, the remainder having started English five years later. One of the main goals was to analyse how literacy skills in the home language(s) affected literacy development in the target language English - i.e. to discover if performance at the beginning of secondary school in one language (German) predicted performance at the end of secondary school in the other language (English) - and how age of onset (AO), family circumstances and type of bilingualism related to the results. This latter dimension was assessed through the inclusion of four participant groups: monolinguals, simultaneous bilinguals with biliteracy skills (i.e., children who grew up with two home languages before learning English in school), simultaneous bilinguals without biliteracy skills and sequential bilinguals. The results revealed the mitigating influence of the hybridity of experiences of bilinguals on AO effects: both bilingualism and biliteracy effects interacted with a supportive learning environment. Quality in the home environment seemed to be important regardless of differences in AO or biological age (see also Pfenninger \& Singleton, 2018). The beneficial effects of parental sensitivity connect well with the bilingualism literature. For instance, family circumstances in which bilingualism is valued provide children with the opportunities to use and switch between two languages, which in turn could enhance their executive functions (see Goriot et al., 2016). 
An earlier starting experience proved beneficial for just one specific learner group: simultaneous bilinguals who were biliterate and had in addition received substantial parental support. The parents of these children reported more a very positive, active role in their children's learning and multilingualism. This may explain the age effects reminiscent of "earlier=better" findings in naturalistic settings: the intense parental involvement in the case of the group in question approximates to naturalistic conditions at least regarding affective dimensions and the sense of personal and family relevance with which it must imbue English. Young naturalistic L2 acquirers are often aware of the role their L2 proficiency plays in their well-being (friendships, etc.) but also of family approval for such proficiency because of its usefulness to the family. When parents intensely encourage and support school learning of an additional language, the child must have a similar sense of this learning having family relevance and integration.

The results from this study have important educational implications in light of the increasing number of students with an immigrant background, who, in the early primary grades, may have to learn and become literate in two languages beside their home language.

\section{Summary}

Although research often finds evidence of a strong correlation between L1 and L2 literacy skills, it is premature to interpret such evidence as favouring the notion of the interdependence of literacy skills across languages, as other explanations are possible. Moreover, the evidence is mixed.

The widespread belief that the L1 needs to be developed to a certain level in order to guarantee successful cognitive and linguistic benefits from L2 education runs into the empirical problem that developmental thresholds are difficult to define independently and so yield predictions that cannot be refuted.

Some very recent research found that an earlier starting experience in an additional language proved beneficial for a very specific learner group: simultaneous bilinguals who were already biliterate and who received substantial parental support. This finding would appear to have important educational implications.

Recommendations: Despite contradictory evidence regarding L1-L2 interdependence effects, educators and policy makers should, nevertheless, understand that mastering literacy skills in the primary school years is important for students attempting to learn L2s, considering the much stronger effect of (bi)literacy skills compared to effects of age of onset (AO). 


\section{The motivational dimension of early instructed FL learning}

A common view is that younger learners show markedly better attitudes toward learning foreign languages than older learners (see, e.g. Cenoz, 2004; MacIntyre et al., 2002; Nikolov, 1999), which Kanno (2007) relates to the enthusiasm younger learners show in response to new challenges in contrast with the selfconsciousness afflicting adolescents (Driscoll, 1999). Caution is, however, required around the claim that primary school beginners demonstrate more positive attitudes to L2 use than secondary learners. For instance, the quality of early instruction might negatively affect motivation. Early learners may begin with enthusiasm but the teaching approach and/or skills experienced may not be such as to sustain such enthusiasm (see Csizér \& Dörnyei, 2005). For instance, Mihaljevic Djigunovic (1993) observed that her 7-year-old participants did not list foreign languages among their favourite school subjects, possibly because games and other kinds of play, which constituted a large part of the L2 curriculum, bored them. Mihaljevic Djigunovic and Krevelj (2010) note that when conditions are less than ideal (large groups, two lessons per week, unqualified teachers) young L2 learners quickly develop negative attitudes. According to Ushioda (2013) such early dislike may have damaging long-term consequences, as the first contact with the L2 may permanently influence learners' attitudes and motivation (see Singleton \& Ryan, 2004). Early adolescence is associated with flux - a period when learners "struggle to achieve a coherent sense of self" (Lamb, 2012, p.19). Sometimes older learners are described as tending to reject the school system in general, or as being less motivated by the use of more traditional methods in high school (e.g., Tragant, 2006). This, however, does not explain the fact that older starters ubiquitously experience a faster rate of learning than younger starters initially (see e.g., Muñoz, 2006). This phenomenon is often ascribed to their cognitive advantages regarding testing. However, there is also a motivational dimension to this picture. Late starters seem to feel the urge to achieve proficiency quickly. Snow and HoefnagelHöhle (1978) hypothesize that the superior initial performance by older starters is perhaps due to the greater academic demands placed on them by schools, creating higher levels of motivation in them than in younger learners.

In any case, Muñoz (2008) cautions against confounding biological age with age of onset: the finding that younger starters may have a more positive attitude towards learning L2s than older starters may relate to their chronological age rather than, or in addition to, their earlier start (i.e., an earlier start does not guarantee that learners remain motivated as they get older). With respect to the interaction between $\mathrm{AO}$ and motivation it is difficult to draw firm conclusions, particularly since $\mathrm{AO}$ is often confounded with length of instruction and because the research evidence, is inconclusive - see the following. Larson-Hall (2008), in 
her study of attitudes towards language learning in general and specifically the learning of English, found no differences between learners with an early (8 years) versus a late (12 years) learning start.

Tragant (2006) questions sustainability in contexts where L2 instruction is limited to one or two sessions a week, mentioning "the serious risk that students will have difficulty in seeing any progress over time" (p. 237), impacting negatively on motivation and perseverance (see Moyer, 2004; Williams, Burden, \& Lanvers, 2002). Burstall (1975) observed that the motivation to learn French as a school subject decreased after age 10/11. Likewise, Masgoret et al. (2001) report a decrease in motivation with age among Spanish students between 10 and 15. Williams, Burden and Lanvers (2002) analysed the L2 learning motivation of 228 English secondary school students at different ages and found a clear decrease in motivation with years of instruction.

By contrast, studies carried out in Catalonia (e.g., Muñoz, 200o; Muñoz \& Tragant, 2001; Tragant, 2006) found no significant differences in motivation between learners starting at age 8 and age 11. They did, however, observe that the learners' age had an effect on the type of motivational orientation that students had. As opposed to primary school learners, secondary school students had increasingly higher levels of instrumental motivation, seeming to be more aware of the importance of English as an international language (Tragant, 2006). Not only motivation but also goalposts change over a period of learning (e.g., Henry, 2014).

Despite the negative image of the small amount of exposure and large time distribution in typical early L2 programmes, it may not be impossible for students to maintain high motivation levels over a long period of time - they may simply "need to develop ... skills and strategies to keep themselves on track" (Ushioda, 2008, p. 26) - e.g., by "engaging in... intrinsically motivating activity" (Ushioda, 2008, p. 27). Tragant (2006) found that learners of the same age (12;9) but with different amounts of instruction (200 vs. 416 hours), showed similar levels of motivation and similar types of orientation ("Instrumental" and "Communication/ travel" orientations ranking very high). Significant differences were only found later: after 726 hours of instruction, more students had positive attitudes towards learning English among those who had started at the age of 11 (89.7\%) than among those who had started at the age of 8 (71.2\%). Tragant (2006, p. 257) concludes that biological age is a more determinant factor than amount of instruction received see also Gonzales (2010).

Finally, Pfenninger \& Singleton's (2016a) results questioned the view that the main benefits of early L2 learning lie in the development of positive attitudes and motivation. Positive attitudes were not associated with biological age either. Younger learners were not more motivated than older learners; on the contrary, 
almost all motivational orientations received higher values at the end of secondary school).

In Pfenninger \& Singleton (2016a) the results revealed that the late starters were able to catch up within six months of secondary school with the early starters, who had an advance of five years of English instruction in primary school, with respect to a range of measures, and were able to remain on a par with the early starters until the end of obligatory schooling in Switzerland. With reference to possible reasons for the "kick start" of the late starters in the initial stages of FL learning, the indications were that for the late starters, motivation was more strongly goal- and future-focused at their first measurement, while the motivation of the early starters was predominantly influenced by (present and past) cumulative experiential factors. Since future selves - but not present selves - had a strong impact on FL achievement, this implies that the late starters were able to profit from their orientations at the beginning of secondary school.

In Pfenninger \& Singleton (2016b) we used qualitative data gathered from our focal group of 40 participants to explore aspects of the study that could not be quantified. We were particularly interested in beliefs about the age factor elicited via essays. Touching on motivation, we found that attitudes and beliefs, e.g., preconceived ideas about the age factor and early vs. late FL programmes, affected learners' approach to language learning. Moreover, class size was a strong predictor of FL outcomes irrespective of $\mathrm{AO}$ - perhaps because of the impact of class size on motivation. Finally, the broader social and educational school context played an important role in attitude formation and in influencing students' future L2 selfstates. While the late starters seemed content on the whole with the conditions of their later start, the early starters had to deal with a range of challenging aspects of FL-related experiences at the beginning of secondary school, such as adjusting to the new teaching style. In other words, apart from the intrinsic qualities, favourable or otherwise, of the early English experience, there were difficulties associated with the perceived lack of a smooth join between primary and secondary levels of education, all of which are will be discussed in what follows.

\section{Summary}

The popular assumption that primary school L2 learners are generally better motivated than older learners is not borne out by research. Any initial flourishing of motivation amongst younger beginners seems often to be shortlived. Positive motivation, on the contrary, appears to be associated with the onset of secondary schooling, with late starters feeling the urge to attain to proficiency quickly.

It has to be said also that the motivational state of younger beginners may relate to their biological age rather than their age of encountering the L2. Age of 
onset is also confounded with length of instruction. One interesting finding is that type of motivation many change, with secondary school students evidencing more instrumental motivation.

In this connection, some recent research indicates that for the late starters motivation is more strongly goal- and future-focused than for early starters, but also that the broader social and educational school context plays an important role in attitude formation.

Recommendations: "The earlier the better" or "the later the better" are specific postulates that can be related to a set of beliefs about age and the time and effort investment necessary to really succeed in L2 learning. It is in this context vital to strengthen the belief in the efficacy of in-school learning environments among young learners in primary school.

\section{Transition from primary to secondary school}

Motivation and the continuous development of language proficiency may depend on a successful transition from primary to secondary education (Jaekel et al., 2017). This transition has often been described as a fragile moment, as it features elements which may be difficult to understand or manage (Blondin et al., 1998; Jones, 2016). With respect to FL learning, the transition from a more communicative and holistic approach to FL learning at primary level to a more formal and consciousness-engaging approach at secondary level is sometimes experienced as problematic by students and teachers alike (see Muñoz, Tragant, \& Camuñas, 2015). It is thus important to take account of students' perspectives on the dis/continuity of their language journey. Several critical issues in relation to the transition from FL instruction in primary to secondary school have been identified in the recent literature:

1. Several issues in relation to the transition from FL instruction in primary to secondary school have been discussed in the recent literature (Chambers, 2014; Courtney, Graham, Tonkyn, \& Marinis, 2015; Graham et al., 2016; Jaekel et al., 2017; Muñoz et al., 2015; Nikolov \& Mihaljevic Djigunovic, 2011; Pfenninger \& Lendl, 2017): An abrupt shift from student-centred, "implicit" methodology to more teacher-directed and faster-paced lessons may disturb young learners. 
2. There is a possible mismatch of student-teacher expectations regarding teaching methods, which may cause a decrease in motivation, particularly if instruction is not suited to students' proficiency level.

3. Coordination and even communication between primary and secondary school teachers is usually lacking.

4. L2 proficiency outcomes from primary schools vary greatly; thus, since secondary schools receive students from several primary schools, teachers are required to be particularly thorough in assessing the initial skills of incoming students.

5. Primary school L2 teachers are sometimes not trained extensively, as L2 programmes are still relatively new to primary education in some countries.

Nikolov (2017) points out that what children in Hungary learn in their FL in their first years will be forgotten unless revised and built on in a regular fashion in later years. She emphasizes that raising children's interest is easy but maintaining their motivation over years poses a challenge (see above). Nikolov speculates that loss of motivation may sometimes be caused by disappointing test results

Pfenninger and Lendl's (2017) portrayal of the impact of L2 instruction dis/ continuity from primary to secondary school is, however, more complex. They analysed the degree of continuity between input received in primary school and secondary school, as well as learners' beliefs, attitudes and self-efficacy before and after they moved to secondary school. Twelve primary schools and six secondary schools in Switzerland participated in the study, with a total of 280 early learners of EFL (age of onset: 8 years) who were tested at the end of primary school and at the beginning of secondary school, respectively. Results of linear mixed-effects regression models revealed that there did not seem to be a general problem with the change of teaching approach from primary to secondary school, as has been suggested (see above). Rather, the abandonment of certain implicit activities (e.g., singing songs and playing), creates the impression that a new start in a secondary school involves the risk of loss of what was learned in primary school.

Muñoz, Tragant and Camuñas (2015) caution that if students are not made aware of their implicit knowledge in primary school, they may have the sense that their learning before transition has not prepared them for the "new" classroom activities. This results in some learners' undervaluing whatever L2 knowledge they brought with them. Muñoz and colleagues reason such undervaluing of what was learned in primary school may lead to the perception of secondary school as a completely new start. Another noteworthy result in both their quantitative and their qualitative analyses relates to the repetitive nature of EFL in secondary school i.e., there was widespread comment on apparent repetition by secondary teachers of work already covered in primary schools. 
Students' responses also raise the question of whether the skills acquired at primary school are adequately recognized at secondary school. Many authors (e.g., Muñoz et al., 2015) have suggested that constantly repeating content and activities may have implications for learners' sense of progress. Ushioda (2014, p. 135) suggests that social-environmental conditions that undermine learners' sense of competence will generate forms of motivation that are less internalized and more externally regulated by environmental influences and controls (see also Jones, 2016).

In contrast, Pfenninger \& Lendl (2017) suggest that there are also many learners who report similarly high levels of enjoyment for English at the start of secondary school as at the end of primary, particularly owing to repeated content in secondary. This is in line with previous work by Courtney et al. (2015), who found that their learners of French did not object to covering familiar content on reaching the first year of secondary school, as it enhanced their sense of making progress by consolidating their knowledge and skills. Similarly, Graham et al. (2016) found that total motivation scores increased at significant levels across the point of transition, and at the end of the first year of secondary were still significantly higher than in the last year of primary.

Besides individual variation, school and class diversity also displays a significant role, particularly in primary school data. Primary school groups can be very heterogeneous in terms of level. This inevitably leads to "mixed ability classes" with a risk of frustration and boredom on the part of the higher-proficiency learners and to feelings of being overtaxed among lower-proficiency students. Pfenninger and Singleton $(2016 \mathrm{~b}, 2017)$ discuss how this situation may mitigate the potential advantages of an earlier L2 start. Furthermore, the participants originate from different school districts and experience emphases on different skills and values (see Pfenninger \& Singleton, 2016a).

In many countries students are streamed into different branches of secondary school. Pfenninger (2017) found significant variability in AO effects across the five schools in her investigation at the beginning but not at the end of secondary school, showing that secondary schools may reduce inequalities between different groups over time. A further difficulty with the move into secondary school may stem from variability in the amount and quality of FL teaching at primary school which leads some secondary schools to start language instruction from scratch with all learners, regardless of previous learning.

Finally, a word on the implicit-explicit dichotomy. The precise meaning of implicit and explicit and the nature of their differentiation are not universally agreed upon - and this comment applies whether one is talking about learning, teaching approach or knowledge (see Mitchell, Myles, \& Marsden, 2013, pp.136-137). The implicit dimension is generally thought of as drawing on 
as an automatic, non-conscious and powerful mechanism that results in knowledge which can be accessed quickly and without effort (Dörnyei, 2009; Ellis, 1994). It is claimed to enable "learners to infer rules without awareness" and "internalize the underlying rule/pattern without their attention being explicitly focused on it" (Ellis, 2009, p.16). Implicit learning is also seen as a process that requires intensive exposure to input over a prolonged period of time (Tellier \& RoehrBrackin, 2017). By contrast, the explicit dimension is characterized as involving "conscious awareness on the part of learners as they attempt to understand material, ... to analyze input, or ... to solve production or comprehension problems" (Tellier \& Roehr-Brackin, 2017). However, explicit learning is portrayed as resource-intensive, requiring attention and relying on the processing and maintenance of information in working memory (Jaekel et al., 2017). For this reason (more) mature learners have been considered to be better able to learn explicitly (Jaekel et al., 2017). Thus, younger children's poorer performance in classroom settings compared with older children, adolescents and adults is normally attributed to their relative lack of cognitive maturity, their exposure to minimal input, and their predominant reliance on implicit learning - purportedly slow and requiring considerable input to be effective (Tellier \& Roehr-Brackin, 2017).

\section{Summary}

The transition between primary and secondary school has often been characterized as a delicate moment in a child's L2 schooling. Among issues that have been raised in the literature are included: the shift from student-centred, "implicit" methodology to more teacher-directed classes; the possibility of a mismatch between student and teacher expectations regarding teaching methods; an absence of coordination/communication between primary and secondary school teachers; the fact that L2 proficiency outcomes from primary schools feeding a given secondary school may vary greatly; and the lack of adequate training exhibited by primary school L2 teachers in some countries.

Some research suggests not that students have a general problem with the change of teaching approach from primary to secondary school, but rather that the abandonment of certain implicit activities suggests to them that secondary school involves the risk of loss of what was learned in primary school. Relatedly, the frequent repetition in secondary school of material covered in primary school raises the question of the extent to which the covering of such material at primary level is taken account of or valued at secondary level. On the other hand, some recent studies show that secondary level learners have no problem with covering familiar content on reaching secondary school, seeing it as enhancing their sense of making progress by consolidating their knowledge and skills. 
It is something of a cliché that primary school students excel in the domain of "implicit" learning and secondary school students in the domain of "explicit" learning, and that the reason for the disappointing performance of the former in dealing with L2s is that what they encounter at school does not feed their implicit needs. In this context it is perhaps worth remembering that the precise meaning of implicit and explicit and the nature of their differentiation are by no means universally agreed upon.

Recommendations: The transition from FL learning in primary to FL learning in secondary must be given more attention as a possible factor in students' levels of attainment. Secondary teachers need to be particularly thorough in assessing the L2 skills that students entering their class have already attained. In addition, students need to be made aware of the implicit knowledge they have acquired in primary school.

\section{Intensity versus quantity of instruction}

It is recognized that a few hours a week of exposure to a new language, even if continued for several years, does not allow students to attain very high levels of L2 proficiency (Collins \& White, 2011). Accordingly, interest has shifted from regular, low-input FL programmes to different types of intensive language programmes. In general, a course or programme is deemed intensive when the hours available for instruction are concentrated in blocks of time, giving students exposure to the L2 for several hours a day. The length of the intensive experience varies widely across countries and programmes, however, as does the corresponding terminology. For instance, while some (e.g., Maillat, 2010) consider 'Content and Language Integrated Learning (CLIL)' to be a specific form of 'immersion', for others (e.g. Baetens Beardsmore, 2002), CLIL is the general construct under which a variety of alternative forms of integrated language and content instruction can be placed, including immersion, involving a FL or a lingua franca (usually English) not present in the learners' environment. Yet others (e.g., Kovelman et al., 2008) use the terms 'bilingual (language) exposure' and 'bilingual education' to refer to intensive, systematic, and maintained exposure to a child's new language. Intensive programmes may have the potential to break through the attainment ceiling typically associated with early L2 learning without necessitating changes in the time allotted to the different school subjects. This is the promise of CLIL (see Genesee \& Gorter, 2014; Marsh, 2002), where an additional language is used "for the learning and teaching of both content and language" (Coyle, Hood, \& Marsh, 2010, p.1). 
The idea is that proficiency will be developed in both the non-language subject and the language in which it is taught (Lasagabaster, 2011; but see Coyle, 2008; see also Cenoz et al., 2014; Mehisto, 2008; Pérez-Vidal \& Juan-Garau, 2010).

There appear, in this context, to be limitations on the L2 learning advantage when the to-be-learned targets are more closely related to the types of skills typically associated with L2 learning (Collins \& White, 2011,p.110). On the other hand, there is consensus that students in concentrated programmes generally acquire higher levels of proficiency in the L2 than students in programmes with normally spaced L2 units of contact. Netten and Germain's (2004) study of intensive vs. non-intensive L2 French programmes in Quebec showed that traditional L2 language programmes with limited hours of instruction per week in a nonconcentrated time distribution were relatively less effective. Serrano and Muñoz's (2007) results show that those L1 Spanish students registered in extensive classes make less progress than those in intensive groups (the hours of instruction being the same in the different language programmes). Hinger (2006) observed that students in intensive groups have more group cohesion and are more motivated than students in regular classes. Similarly, the intensive group students in the studies by MacFarlane et al. (2004) and Peters (2000) seemed to display more selfconfidence and positive attitudes towards learning the L2. Learners are known to progress more slowly in "normal" primary school, possibly because they have not enough time and exposure to benefit from implicit learning (see De Graaff \& Housen, 2009).

A problem of the "normal" primary regime is the risk that students may have difficulty seeing any progress over time, which may lead to frustration (see above). Thus, students who have intensive exposure to the FL appear to have an advantage over those whose instruction is thinly spread over a longer period of time (Muñoz, 2012; Netten \& Germain, 2004; Serrano \& Muñoz, 2007).

A considerable amount of CLIL research has been carried out over the last twenty years, and various benefits of CLIL have been noted, such as the following (from Pfenninger, 2016). Because of the higher amount and intensity of exposure to the L2, on the one hand, and the opportunities for engaging in authentic and meaningful interaction in real-life contexts; on the other, immersion students have been found to be more successful than students receiving "normal" FL instruction, particularly with respect to receptive skills, oral fluency, syntactic complexity, lexical range and confidence/risk-taking in the target language (e.g., Collins \& White, 2011, 2012; Spada \& Lightbown, 1989; de Zarobe \& Jiménez Catalán, 2009). 
1. CLIL students have been reported to demonstrate better verbal and nonverbal communication skills, cognitive skills and divergent thinking than their non-CLIL counterparts (Vesterbacka, 1991).

2. The above benefits have emerged both when concentrated exposure has been regular and when it has been supplied in short intensive experiences (e.g., Collins \& White, 2011, 2012).

3. CLIL is claimed to minimize the role that individual differences, such as language learning aptitude, plays in more limited exposure situations (e.g., Collins \& White, 2011, 2012).

4. CLIL increases exposure to the target language without taking up more time in an already crowded school timetable (e.g., Lasagabaster, 2011).

5. Content knowledge appears to remain on a par with that learned through the L1 (e.g., Admiraal, Westhoff \& de Bot, 2006; Genesee, 2004; GoorhuisBrouwer \& de Bot, 2010).

6. L1 skills development is very similar both in CLIL classes and in non-CLIL classes (e.g., Seikkula-Leino, 2007; Vesterbacka, 1991).

7. Owing to the higher exposure to the FL than in regular programmes, CLIL programmes seem to foster implicit learning, which has been identified as a highly effective way of learning (Coyle, 2008; de Graaff \& Housen, 2009; DeKeyser, 2000; Hulstijn, 2002).

8. Related to point (8), CLIL is age-appropriate in elementary schools, since younger children (e.g., in early FL programmes) cannot attend to formal, explicit L2 instruction to the same extent as older children (see e.g., Ellis, 2002).

Collins \& White (2011) analysed the oral and written production and of aural and written comprehension of 230 Grade 6 (aged 11-12 years) francophone children who had begun learning English as a second language (ESL) in Grade 3 (age 8). They were in one of two versions of a similar intensive English as an L2 programme which differed with respect to how the instructional time was distributed: in one programme, the 400 hours of instruction were concentrated in a 5 -month block (full days of English every day for 5 months); in the other, the 400 hours were experienced in a series of intensive exposures across the full 10-month academic year. While Collins \& White found substantial progress over time for both of the two programmes, they reported significant differences on a third of the measures in favour of the concentrated group. However, since the effect sizes were rather small and there was a number of intervening variables such as differences in the pedagogical contexts, the authors concluded that "it is not possible to argue with confidence that students in the concentrated model were superior in listening, use of verb inflections, or overall performance as a direct result of the distrib- 
ution of instructional time" (p.126). In addition, whether more advanced learners would have extracted greater benefit from a single intensive experience than several shorter ones remains an empirical question.

While numerous studies (e.g., Admiraal et al., 2006; Dalton-Puffer, 2007; de Zarobe, 2008) have confirmed the benefits conferred on CLIL/immersion learners versus non-CLIL learners, there has been some questioning of conclusions drawn from CLIL research (e.g., Bruton, 2011; de Zarobe, 2011). Some of the issues and questions that have emerged in the present study and that need to be addressed and considered in future research are listed in the following (see Pfenninger, 2014).

1. Because of the diversity of CLIL programmes and the lack of conceptual clarity (see Cenoz et al., 2014, p. 257), it is difficult for researchers to provide a clear characterization of CLIL programmes.

2. One limitation in studies comparing CLIL and non-CLIL programmes is that since the CLIL groups not only have language classes, but also school subjects taught in the relevant language, two variables are conflated: type of instruction and exposure (see Bruton, 2011; Cenoz et al., 2014).

3. Two factors that need to be controlled for are L2 learning motivation and aptitude. Motivation is probably one of the most crucial factors in studies on the outcomes of CLIL, considering that CLIL programmes are often not available for all students, which leads to a selection of students for these programmes "who will be academically motivated to succeed" (Bruton, 2011, p.524).

4. It is also interesting to analyse which other input measures (length of instruction, number of curricular and extracurricular lessons, time spent in a naturalistic immersion situation, current informal contact with the target language) are strongly associated with long-term L2 performance

Collins, Halter, Lightbown and Spada (2012) addressed the issue with the conflation of type and intensity of instruction (point 2) by comparing distributed vs. massed ESL instruction of the same type: Nine Grade 6 classes from a distributed programme ( 2 hours per day of exposure to English over the full 10 months of one school year), 12 from a massed programme (full ESL immersion for 5 months of one school year), and 5 from a massed-plus programme ( 5 months in full-day intensive ESL classes incl. extracurricular exposure to English). The most successful outcomes in the Collins et al. study were observed in the massed-plus students who surpassed students in the other programmes, even when those students had begun intensive ESL with more knowledge of English and even when those students had a history of being more academically successful. Since the participants were drawn from a wide range of academic abilities, thus circumventing the problem with self-selection (point 3 above), Collins et al. conclude that "superior aca- 
demic ability is not a requirement for successfully learning English in intensive communicative classes" (p. 671).

With respect to CLIL and time and timing, Muñoz (2015) has hypothesized that the higher intensity of exposure to the TL provided by programmes programs may yield different results, younger learners having more opportunities to use their implicit learning mechanisms advantageously. An opposite prediction could be that older learners may benefit from increased cognitive abilities and more advanced L1 academic proficiency. North American research found evidence against the "earlier is better" trend also in full immersion programmes (Genesee, 1981), students in later immersion programmes performing as well as students immersed earlier (but see Wesche et al., 1996).

In the ELIAS project (e.g., Kersten et al., 2010), researchers from Belgium, England, Germany and Sweden monitored children's progress in L2 acquisition, intercultural communication, bilingual science skills and environmental awareness in bilingual preschools. It emerged that increased L2 contact duration and L2 input intensity positively affected receptive grammar and receptive vocabulary knowledge, and that the children's L1 was not negatively affected by the use of English in bilingual preschools (see also Hiligsmann et al., 2013; Juan-Garau \& Salazar-Noguera, 2015). Pfenninger and Singleton (2017) found that students in late CLIL classes (secondary level) in Switzerland had significantly more positive attitudes towards English than those in regular EFL classes. However, while the CLIL approach had a motivating effect on the learners, CLIL students tended to be more motivated than students in regular FL classes from the beginning.

Finally, a few studies have investigated the benefits of CLIL at different ages. Through the reanalysis of empirical studies with a quantitative approach to language gains, Muñoz (2015) investigated how different age groups benefit from content-based language teaching. What emerges is that English learners who begin CLIL instruction later in primary school reach equivalent proficiency levels to learners who have been in the CLIL programme since the beginning of primary education and display faster rates of FL learning (see also Lorenzo et al., 2010). In a recent study on the question of how much additional exposure to the FL through CLIL is necessary for learners to enjoy linguistic gains, Artieda et al. (2017) analyzed two different constellations of partial CLIL instruction in Spanish secondary school: two groups of students with similar hours of instruction but different ages in two contexts - formal instruction (FI) and CLIL - and students with the same age but different hours of instruction). Keeping starting age constant, they found that CLIL learners need to be up to two years younger than their FI counterparts to outperform them with the same number of hours of instruction. When matched for age, the group with extra CLIL hours significantly outperformed the FI-only group on most measures. 
Kovelman et al. (2008) analyzed how age of first bilingual language exposure affects reading development in children learning to read in two languages and whether there is a reading advantage for monolingual English children educated in bilingual schools. On the one hand, they found that children from monolingual English homes attending bilingual programmes, experience a reading development advantage over monolingual children in monolingual reading programmes. On the other hand, an early age of first bilingual language exposure had a positive effect on reading, phonological awareness, and language competence in both languages.

Regarding CLIL in primary education, Egiguren (2006) investigated two groups of bilingual Basque-Spanish students. One group started English at age 4, and the other at 8. When their English proficiency was compared at age 10, no differences were found: late starters had caught up with early starters in only 1.5 years. Most age and CLIL studies in SLA have based their conclusions on group data at one moment in time, on measurements at two data points, or on crosssections comparing groups of learners at different levels. By contrast, Pfenninger (in prep.) focuses not only on the learning process and on quantification of change but also on the underlying environmental and psychological reasons for change. She explores the best time and timing for bilingual language exposure in Swiss immersive (pre)primary programmes with $50 \%$ of the content being taught via the community language German and 50\% via English. Data collection occurred four times annually over eight school years (ages 5-12), via oral and written production tasks and language awareness questionnaires. Results showed that bilingual exposure may afford a powerful positive impact on L2 development compared to regular FL instruction, but it shows similar starting age effects as the latter: $\mathrm{AO}$ seems to have an effect on some measures (e.g., fluency) but not others (e.g., lexical richness). However, while children with AOs 5 and 7 respectively had almost identical developments, i.e., they only differed at the very end at age 12, there are significant differences between students with an $\mathrm{AO}$ of 9 and the other groups almost all the way through. It does not seem to matter whether children begin a bilingual programme at the age of 5 or 7 , but those who begin at 9 do not manage to catch up with the rest by the end of primary school. Results also showed that in L2 development many internal states (e.g., motivation, attitude, etc.) and external states or events (the general learning context or family circumstances) at any given moment may have an effect on the developmental path. All these interrelated factors may cause any part of the learner's L2 system to fluctuate from one moment to the next. Finally, the study illustrates that the developmental process of the different $\mathrm{AO}$ groups can only be approximated by extended time series and cannot be inferred by measurements at one or two points in time. In other words, con- 
clusions about the eventual attainment are strongly dependent on the coincidental time of the measurement (see also Lowie \& Verspoor, 2015).

\section{Summary}

In relation to the question of the mode in which L2 exposure is best delivered at primary level much attention has focused in recently on Content and Language Integrated Learning (CLIL), which provides teaching via the L2 of some of the school subjects. CLIL has been claimed to bestow numerous benefits: better communication skills; efficacy whatever the degree of teaching intensity; the minimization of the role of individual differences; an increase of L2 exposure without taking up more time; a preservation of the level of content knowledge to that learned through the L1; very similar L1 skills development to that attained in nonCLIL classes; and the fostering of implicit learning, allegedly a highly effective way of learning and age-appropriate at primary school. Assessing such claims as the above is difficult in the light of the diversity of CLIL programmes, the conflation of the two variables type of instruction and exposure, the fact that students are often selected for these programmes and are thus ab initio motivated to succeed, and the puzzle of which other input variables might be associated with long-term L2 performance.

Opinions differ as to which age-category of students benefit more from high intensity teaching. Although it seems that early L2 immersion students are not in the long run advantaged over late L2 immersion students, some research has found that increased L2 contact duration and L2 input intensity in pre-secondary education positively affects receptive grammar and receptive vocabulary knowledge, and that the children's L1 is not negatively affected by the use of the L2 in bilingual preschools. Other research indicates that bilingual exposure may have a powerful positive impact on L2 development compared to regular L2 instruction, although it shows broadly long-term similar starting age effects as the latter.

Recommendation: An intensive language learning experience can lead to substantial progress in an L2 in a relatively short amount of time, for both children and adults, early and late starters. In particular bilingual programmes in (pre)primary school seem to cater to children's natural language learning ability. The distribution of substantial amounts of FL instructional time - concentrated in an uninterrupted learning experience or distributed across a series of successive intensive experiences - also seems to affect learners' L2 proficiency in favour of a single, sustained intensive exposure to the L2. 


\section{Conclusion}

So what messages can we gather from the foregoing? One clear point that we have to take in board is that the question of the extent to which L2 user's languages are interdependent is of key importance in the policy discourse on language education (Berthele, 2017). The answer to this question is not as straightforward as some earlier attempts to address it may have implied, but it needs to remain constantly before us, and it needs further and deeper investigation.

Another key element that we need to fully acknowledge is that the problems surrounding the early teaching and learning of L2s are not only concerned with the role of physiological maturation and degree of intensity of instruction. There are patently a number of broader macro-institutional factors that may impede the goal sought by the offering of numerous years of continued FL instruction.

Also to be weighed is the impact which classroom experiences seem to have on attitude and motivation in regard to influencing learners' perceptions of progress and competence. According to some accounts, this impact may be especially strong around the time of primary - secondary transition, at a point when such a sense of competence becomes particularly important for learners.

It appears from our discussion that early start to FL instruction under certain conditions may have a favourable outcome, in terms of the legacy it gives to the child for the later school years and maybe life. We can perhaps set aside in this context the question of whether "earlier is better", and simply recognize the fact that under optimal learning circumstances (that is, high quality, quantity and intensity of input in a naturalistic setting, ample opportunities for interaction with a variety of native speakers, high motivation, etc.) experiencing a foreign language at an early age of may have positive consequences.

Finally, we have to take very seriously the evidence that the broader learning environment seems to be more influential than the cognitive state assumed to be a characteristic of the individual. Accordingly, a simple (nay, simplistic) individual difference model, which assumes that age is a fixed factor is not at all satisfactory. Age of onset interacts not only with environmental contingencies to create a synergistic effect, but it is also influenced, mediated and mitigated by environmental influences.

\section{References}

Admiraal, W., Westhoff, G., \& de Bot, K. (2006). Evaluation of bilingual secondary education in the Netherlands: Students' language proficiency in English. Educational Research and Evaluation, 12(1), 75-93. https://doi.org/10.1080/13803610500392160 
Alderson, J.C. (1984). Reading in a foreign language: A reading problem or a language problem? In J. C. Alderson, \& A. H. Urquhart (Eds.), Reading in a foreign language (pp. 1-24). London, UK: Longman.

Artieda, G., Roquet, H., \& Nicolás-Conesa, F. (2017). The impact of age and exposure on EFL achievement in two learning contexts: formal instruction and formal instruction + content and language integrated learning (CLIL). International Journal of Bilingual Education and Bilingualism. https://doi.org/10.1080/13670050.2017.1373059

Avineri, N., \& Johnson, E. J. (2015). Bridging the language gap. Journal of Linguistic Anthropology, 25(1), 66-86. https://doi.org/10.1111/jola.12071

Baetens Beardsmore, H. (2002). The significance of CLIL/EMILE. In D. Marsh (ed.), CLIL/EMILE the European Dimension (pp. 24-26). Jyväskylä, Finland: University of Jyväskylä.

Berthele, R. (2017). Assessing heritage languages and interdependence: Why and how? In R. Berthele \& A. Lambelet (Eds.), Interdependence or independence? Heritage and school language literacy development in migrant children (pp. 189-201). Bristol, UK: Multilingual Matters.

Berthele, R., \& Lambelet, A. (2017a). Interdependence or independence? Heritage and school language literacy development in migrant children. Bristol, UK: Multilingual Matters.

Berthele, R., \& Lambelet, A. (2017b). Investigating interdependence and literacy development in heritage language speakers: Theoretical and methodological considerations. In R. Berthele \& A. Lambelet (Eds.), Interdependence or independence? Heritage and school language literacy development in migrant children (pp. 1-26). Bristol, UK: Multilingual Matters.

Blondin, C., Candelier, M., Edelenbos, P., Johnstone, R., Kubanek-German, A., \& Taeschner, T. (1998). Foreign languages in primary and pre-school education: A review of recent research within the European Union. London, UK: CILT.

Bruton, A. (2011). Is CLIL so beneficial, or just selective? Re-evaluating some of the research. System, 39, 523-32. https://doi.org/10.1016/j.system.2011.08.002

Cenoz, J. (2004). Teaching English as a third language: The effect of attitudes and motivation. In C. Hoffmann, \& J. Ytsma (Eds.), Trilingualism in family, school and community (pp. 202-218). Clevedon, UK: Multilingual Matters.

Cenoz, J., Genesee, F., \& Gorter, D. (2014). Critical analysis of CLIL: Taking stock and looking forward. Applied Linguistics, 35(3), 243-262. https://doi.org/10.1093/applin/amto11

Chambers, G. N. (2014). Transition in modern languages from primary to secondary school: the challenge of change. Language Learning Journal, 42(3), 242-26o. https://doi.org/10.1080/09571736.2012.708052

Collins, L., \& White, J. (2011). An intensive look at intensity in language learning. TESOL Quarterly, 45(1), 106-133. https://doi.org/10.5054/tq.2011.240858

Collins, L., \& White, J. (2012). Closing the gap: Intensity and proficiency. In C. Muñoz (Ed.), Intensive exposure experiences in second language learning (pp. 45-65). Bristol, UK: Multilingual Matters. https://doi.org/10.21832/9781847698063-006

Courtney, L., Graham, S., Tonkyn, A., \& Marinis, T. (2015). Individual differences in early language learning: A study of English learners of French. Applied Linguistics, 38(6), 824-847. https://doi.org/10.1093/applin/amvo71 
Coyle, D. (2008). CLIL: A pedagogical approach from the European perspective. In N. Van Deusen-Scholl, \& N.H. Hornberger (Eds.), Encyclopedia of language and education (pp. 97-111). New York, NY: Springer. https://doi.org/10.1007/978-0-387-30424-3_92

Coyle, D., Hood, P., \& Marsh, D. (2010). CLIL: Content and language integrated learning. Cambridge, UK: CUP.

Csizér, K., \& Dörnyei, Z. (2005). Language learners' motivational profiles and their motivated learning behaviour. Language Learning, 55(4), 19-36. https://doi.org/10.1111/j.0023-8333.2005.00319.x

Cummins, J. (1976). The influence of bilingualism on cognitive growth: A synthesis of research findings and explanatory hypotheses. Working Papers on Bilingualism, 9, 1-43.

Cummins, J. (1978). Bilingualism and the development of metalinguistic awareness. Journal of Cross-Cultural Psychology, 9(2), 131-149. https://doi.org/10.1177/002202217892001

Cummins, J. (1979). Linguistic interdependence and the educational development of bilingual children. Review of Educational Research, 49(2), 222-251. https://doi.org/10.3102/00346543049002222

Cummins, J. (2000). Language, power and pedagogy: Bilingual children in the crossfire. Clevedon, UK: Multilingual Matters. https://doi.org/10.21832/9781853596773

Cummins, J. (2001). An introductory reader to the writings of Jim Cummins. Clevedon, UK: Multilingual Matters.

Dalton-Puffer, C. (2007). Discourse in content and language integrated learning (CLIL) classrooms. Amsterdam, Netherlands: John Benjamins. https://doi.org/10.1075/IIlt.20

De Graaff, R., \& Housen, A. (2009). Investigating effects and effectiveness of L2 instruction. In M. Long \& C. Doughty (Eds.), The handbook of language teaching (pp. 726-753). Oxford, UK: Wiley-Blackwell. https://doi.org/10.1002/9781444315783.ch38

DeKeyser, R.M. (200o). The robustness of critical period effects in second language acquisition. Studies in Second Language Acquisition, 22(4), 499-533.

De Zarobe, Y.R., \& Jiménez Catalán, R. M. (2009). Content and language integrated learning: Evidence from research in Europe. Clevedon, UK: Multilingual Matters. https://doi.org/10.21832/9781847691675

Dörnyei, Z. (2009). The psychology of second language acquisition. Oxford, UK: Oxford University Press.

Driscoll, P. (1999). Teaching modern foreign languages in the primary school. Andover, UK: Taylor \& Francis.

Egiguren, I. (2006). Atzerriko hizkunktza goiztiarraren eragina gaitasun eleaniztunean (Unpublished doctoral dissertation). Vitoria-Gasteiz, Spain: University of the Basque Country.

Ellis, N.C. (Ed.). (1994). Implicit and explicit learning of languages. London, UK: Academic Press.

Genesee, F. (2004). What do we know about bilingual education for majority language students. In T. K. Bhatia, \& W. Ritchie (Eds.), Handbook of bilingualism and multiculturalism (pp. 547-576). Malden, MA: Blackwell.

Geva, E., \& Ryan, E. B. (1993). Linguistic and cognitive correlates of academic skills in first and second languages. Language Learning, 43(1), 5-42. https://doi.org/10.1111/j.1467-1770.1993.tboo171.x

Gonzales, R. D. (2010). Motivation orientation in foreign language learning: The case of Filipino students learning foreign languages. TESOL Journal, 3, 3-28. 
Goorhuis-Brouwer, S., \& de Bot, K. (2010). Impact of early English language teaching on L1 and L2 development in children in Dutch schools. International Journal of Bilingualism, 14, 289-302. https://doi.org/10.1177/1367006910367846

Goriot, C., Denessen, E., Bakker, J., \& Droop, M. (2016). Benefits of being bilingual? The relationship between pupils' perceptions of teachers' appreciation of their home language and executive functioning. International Journal of Bilingualism, 20(6), 700-713. https://doi.org/10.1177/1367006915586470

Graham, S., Courtney, L., Tonkyn, A., \& Marinis, T. (2016). Motivational trajectories for early language learning across the primary-secondary school transition. British Educational Research Journal, 42(4), 682-702. https://doi.org/10.1002/berj.3230

Hiligsmann, P., Galand, B., Mettewie, L., Meunier, F., Szmalec, A., \& van Goethem, K. (2013). Assessing content and language integrated learning (CLIL): Linguistic, cognitive and educational perspectives (Unpublished research project). Université catholique de Louvain and Université de Namur.

Hulstijn, J. (2002). Towards a unified account of the representation, processing and acquisition of second language knowledge. Second Language Research, 18(3), 193-223. https://doi.org/10.1191/0267658302sr2070a

Jaekel, N., Schurig, M., Florian, M., \& Ritter, M. (2017). From early starters to late finishers? A longitudinal study of early foreign language learning in school. Language Learning, 67(3), 631-664. https://doi.org/10.1111/lang.12242

Jeong-Won, L., \& Schallert, D. L. (1997). The relative contribution of L2 language proficiency and L1 reading ability to L2 reading performance: A test of the threshold hypothesis in an EFL context. TESOL Quarterly, 31(4), 713-739. https://doi.org/10.2307/3587757

Jones, J. (2016). Transition from primary to secondary language learning: Using an assessment for learning approach to unpack pupils' 'suitcases of skills and abilities'. Babylonia, 2, 79-83.

Juan-Garau, M., \& Salazar-Noguera, J. (Eds.). (2015). Content-based language learning in multilingual educational environments. Dordrecht, Netherlands: Springer. https://doi.org/10.1007/978-3-319-11496-5

Kanno, Y. (2007). ELT policy directions in multilingual Japan. In J. Cummins, \& C. Davison (Eds.), International handbook of English language teaching. Part one (pp. 63-74). New York, NY: Springer. https://doi.org/10.1007/978-0-387-46301-8_6

Kersten, K., Rohde, A., Schelletter, C., \& Steinlen, A. (Eds.). (2010). Bilingual preschools. Vol. I: Learning and development. Vol II: Best practices. Trier, Germany: WVT.

Kovelman, I., Baker, S. A., \& Petitto, L.-A. (2008). Age of first bilingual language exposure as a new window into bilingual reading development. Bilingualism: Language and Cognition, 11(2), 203-223. https://doi.org/10.1017/S1366728908003386

Krompàk, E. (2017). Promoting multilingualism through heritage language courses: New perspectives on the transfer effect. In R. Berthele, \& A. Lambelet (Eds.), Interdependence or independence? Heritage and school language literacy development in migrant children (pp. 142-161). Bristol, UK: Multilingual Matters.

Lamb, M. (2012). A self system perspective on young adolescents' motivation to learn English in urban and rural setting. Language Learning, 62(4), 997-1023. https://doi.org/10.1111/j.1467-9922.2012.00719.x

Larson-Hall, J. (2008). Weighing the benefits of studying a foreign language at a younger starting age in a minimal input situation. Second language research, 24(1), 35-63. https://doi.org/10.1177/0267658307082981 
Lasagabaster, D. (2011). English achievement and student motivation in CLIL and EFL settings. Innovation in Language Learning and Teaching, 5(1), 3-18. https://doi.org/10.1080/17501229.2010.519030

Lightbown, P. (2000). Classroom second language acquisition research and second language teaching. Applied Linguistics, 21(4), 431-482. https://doi.org/10.1177/0267658307082981

Lorenzo, F., Casal, S., \& Moore, P. (2010). The effects of content and language integrated learning in European education: Key findings from the Andalusian bilingual sections. Evaluation project. Applied Linguistics, 31(3), 418-442. https://doi.org/10.1093/applin/ampo41

MacFarlane, A., Peters, M., \& Wesche, M. (2004). Le bain linguistique: Programme intensif de francais langue seconde a Ottawa. Canadian Modern Language Review, 6o(3), 373-391. https://doi.org/10.3138/cmlr.60.3.373

MacIntyre, P.D., Baker, S.C., Clément, R., \& Donovan, L. A. (2002). Sex and age effects on willingness to communicate, anxiety, perceived competence, and L2 motivation among junior high school French immersion students. Language Learning, 52, 537-564. https://doi.org/10.1111/1467-9922.00194

Maillat, D. (2010). The pragmatics of L2 in CLIL. In C. Dalton-Puffer, T. Nikula, \& U. Smit (Eds.), Language Use and Language Learning in CLIL Classrooms (pp. 39-58). Amsterdam: John Benjamins. https://doi.org/10.1075/aals.7.03mai

Martin-Jones, M., \& Romaine, S. (1986). Semilingualism - A half-baked Theory of Communicative Competence. Applied Linguistics, 7(1), 26-38. https://doi.org/10.1093/applin/7.1.26

Marsh, D. (Ed.). (2002). CLIL/EMILE the European dimension. Jyväskylä, Finland: University of Jyväskylä.

Masgoret, A. M., Bernaus, M., \& Gardner, R. C. (2001). Examining the role of attitudes and motivation outside the formal classroom: A test of the mini-AMTB for children. In Z. Dörnyei, \& R. Schmidt (Eds.), Motivation and second language acquisition (pp. 281-296). Hawai' i, HI: University of Hawai'i Press.

McLaughlin, B. (1990). The relationship between first and second languages: Language proficiency and language aptitude. In B. Harley, P. Allen, J. Cummins, \& M. Swain (Eds.), The development of second language proficiency (pp. 158-174). Cambridge, UK: CUP. https://doi.org/10.1017/CBO9781139524568.014

Mehisto, P. (2008). CLIL counterweights: Recognising and decreasing disjuncture in CLIL. International CLIL Research Journal, 1, 93-119.

Mihaljević Djigunović, J. (1993). Investigation of attitudes and motivation in early foreign language learning. In M. Vilke, \& Y. Vrhovac (Eds.), Children and foreign languages (pp. 45-71). Zagreb, Croatia: Faculty of Philosophy, University of Zagreb.

Mihaljević Djigunović, J., \& Krevelj, L. S. (2010). Instructed early SLA: Development of attitudes. SRAZ, 54, 127-146.

Mitchell, R., Myles, F., \& Marsden, E. (2013). Second language learning theories (3rd ed.). London, UK: Routledge.

Moser, U., Bayer, N., \& Tomasik, M. J. (2017). Language skill transfer effects: Moving from heritage language to school language in kindergarten. In R. Berthele, \& A. Lambelet (Eds.), Interdependence or independence? Heritage and school language literacy development in migrant children (pp. 120-141). Bristol, UK: Multilingual Matters.

Moyer, A. (2004). Age, accent and experience in second language acquisition: An integrated approach to critical period inquiry. Clevedon, UK: Multilingual Matters. 
Muñoz, C. (200o). Bilingualism and trilingualism in school students in Catalonia. In J. Cenoz, \& U. Jessner (Eds.), English in Europe: The acquisition of a third language (pp. 157-178). Clevedon, UK: Multilingual Matters.

Muñoz, C. (2008). Symmetries and asymmetries of age effects in naturalistic and instructed L2 learning. Applied Linguistics, 29(4), 578-596. https://doi.org/10.1093/applin/ammo56

Muñoz, C. (2015). Time and timing in CLIL: A comparative approach to language gains. In M. Juan-Garau, \& J. Salazar-Noguera (Eds.), Content-based language learning in multilingual educational environments (pp. 87-104). Berlin, Germany: Springer.

Muñoz, C., \& Singleton, D. (2011). A critical review of age-related research on L2 ultimate attainment. Language Teaching, 44(1), 1-35. https://doi.org/10.1017/S0261444810000327

Muñoz, C., \& Tragant, E. (2001). Motivation and attitudes towards L2: Some effects of age and instruction. In S. Forster-Cohen, \& A. Nizegorodcew (Eds.), Eurosla Yearbook (Vol. 1, pp. 211-224). Amsterdam, Netherlands: John Benjamins.

Muñoz, C., Tragant, E., \& Camuñas, M. (2015). Transition: Continuity or a fresh start? APAC Quarterly, 89, 11-16.

Netten, J., \& Germain, C. (2004). Theoretical and research foundations of intensive French. Canadian Modern Language Review, 6o(3), 275-294. https://doi.org/10.3138/cmlr.60.3.275

Nieminen, L., \& Ullakonoja, R. (2017). The development of Russian heritage pupils' writing proficiency in Finnish and Russian. In R. Berthele, \& A. Lambelet (Eds.), Interdependence or independence? Heritage and school language literacy development in migrant children (pp. 162-188). Bristol, UK: Multilingual Matters.

Nikolov, M. (1999). 'Why do you learn English?' 'Because the teacher is very short.' A study of Hungarian children's language learning motivation. Language Teaching Research, 3(1), 33-56. https://doi.org/10.1177/136216889900300103

Nikolov, M. (2017). Students' and teachers' feedback on diagnostic tests for young EFL learners: Implications for classrooms. In M.P. García-Mayo (Ed.), Learning foreign languages in primary school: Research insights (pp. 249-266). Bristol, UK: Multilingual Matters.

Nikolov, M., \& Mihaljevic Djigunovic, J. (2011). All shades of every color: An overview of early teaching and learning of foreign languages. Annual Review of Applied Linguistics, 31, 95-119. https://doi.org/10.1017/S0267190511000183

Pérez-Vidal, C., \& Juan-Garau, M. (2010). To CLIL or not to CLIL: From bilingualism to multilingualism in Catalan/Spanish communities. In D. Lasagabaster, \& Y. R. de Zarobe (Eds.), CLIL in Spain: Implementation, results and teacher training (pp. 115-138). Newcastle upon Tyne: Cambridge Scholars.

Peters, Martine. (2000). Le bain linguistique: Une innovation pour le programme de francais de base. Apprentissage et Socialisation, 20(2), 71-86.

Pfenninger, S.E. (2016). All good things come in threes: Early English learning, CLIL and motivation in Switzerland. Cahiers de l'ILSL, 48, 119-147. (Special issue, Patricia Ronan (Ed.), Perspectives on English in Switzerland).

Pfenninger, S.E. (in press). Age meets multilingualism: Influence of starting age on $\mathrm{L}_{3}$ acquisition across different learner populations. In C. Bardel \& L. Sanchez (eds.), EuroSLA Studies.

Pfenninger, S.E., \& Singleton, D. (2016a). Affect trumps age: A person-in-context relational view of age and motivation in SLA. Second Language Research. Prepublished 15 January, 2016. https://doi.org/10.1177/0267658315624476 
Pfenninger, S.E., \& Singleton, D. (2016b). The age factor in the foreign language class: What do learners think? Theory and Practice of Second Language Acquisition (TAPSLA), 2(1), 7-23.

Pfenninger, S.E., \& J. Lendl. (2017). Transitional woes: On the impact of L2 input continuity from primary to secondary school. Studies in Second Language Learning and Teaching, 7(3), 443-470. (Special issue, T. Angelovska (Ed.), L2 Grammar Acquisition).

Pfenninger, S.E., \& Singleton, D. (2017). Beyond age effects in instructional L2 learning: Revisiting the age factor. Bristol, UK: Multilingual Matters. https://doi.org/10.21832/PFENNl7623

Pfenninger, S.E., \& Singleton, D. (2019). Starting age overshadowed: The primacy of differential environmental and family support effects on L2 attainment in an instructional context. Language Learning. 69(S1), 207-234. https://doi.org/10.1111/lang.12318

Pica, T. (2011). Second language acquisition research: Applied and applicable orientations to practical questions and concerns. In E. Hinkel (Ed.), Handbook of research in second language teaching and learning (Vol. 2, pp. 257-273). London, UK: Routledge.

Piske, T., MacKay, I. R. A., \& Flege, J.E. (2001). Factors affecting degree of foreign accent in an L2: A review. Journal of Phonetics, 29, 191-215. https://doi.org/10.006/jpho.2001.0134

Riehl, C. M. (2013). Sprachkontaktforschung: Eine Einführung (3rd ed.). Tübingen, Germany: Narr.

Singleton, D., \& Ryan, L. (2004). Language acquisition: The age factor (2nd ed.). Clevedon, UK: Multilingual Matters. https://doi.org/10.21832/9781853597596

Schoonen, R., Snellings, P., Stevenson, M., \& van Gelderen, A. (2009). Towards a blueprint of the foreign language writer: The linguistic and cognitive demands of foreign language writing. In R. M. Manchón (Ed.), Learning, teaching, and researching writing in foreign language contexts (pp. 77-101). Clevedon, UK: Multilingual Matters. https://doi.org/10.21832/9781847691859-007

Schoonen, R., van Gelderen, A., de Glopper, K., Hulstijn, J., Simis, A., Snellings, P., \& Stevenson, M. (2003). First language and second language writing: The role of linguistic fluency, linguistic knowledge and metacognitive knowledge. Language Learning, 53(1), 165-202. https://doi.org/10.1111/1467-9922.00213

Schoonen, R., van Gelderen, A., Stoel, R., Hulstijn, J., \& de Glopper, K. (2011). Modeling the development of $\mathrm{L}_{1}$ and EFL writing proficiency of secondary school students. Language Learning, 61(1), 31-79. https://doi.org/10.1111/j.1467-9922.2010.00590.x

Serrano, R., \& Munoz, C. (2007). Same hours, different time distribution: Any difference in EFL? System, 35(3), 305-321. https://doi.org/10.1016/j.system.2007.02.001

Spada, N., \& Lightbown, P. M. (1989). Intensive ESL programs in Quebec primary schools. TESL Canada Journal, 7, 11-32. https://doi.org/10.18806/tesl.v7i1.557

Sparks, R. (2012). Individual differences in L2 learning and long-term L1-L2 relationships. Language Learning, 62 (Suppl. 2), 5-27. https://doi.org/10.1111/j.1467-9922.2012.00704.x

Sparks, R., Patton, J., Ganschow, L., \& Humbach, N. (2009). Long-term crosslinguistic transfer of skills from L1 to L2. Language Learning, 59(1), 203-243.

https://doi.org/10.1111/j.1467-9922.2009.00504.x

Snow, C., \& Hoefnagel-Höhle, M. (1978). The critical period for language acquisition: Evidence from second language learning. Child Development, 49(4), 1114-1128.

https://doi.org/10.2307/1128751 
Tellier, A., \& Roehr-Brackin, K. (2017). Raising children's metalinguistic awareness to enhance classroom second language learning. In M. P. García-Mayo (Ed.), Learning foreign languages in primary school: Research insights (pp. 22-48). Bristol, UK: Multilingual Matters.

Tragant, E. (2006). Language learning motivation and age. In C. Muñoz (Ed.), Age and the rate of foreign language learning (pp. 237-268). Clevedon, UK: Multilingual Matters. https://doi.org/10.21832/9781853598937-012

Truniger, M. (1998). Sprachenkonzept Schweiz. Zum Unterricht in Migrationssprachen (NichtLandessprachen) innerhalb des Gesamtsprachenkonzepts. Retrieved from $<$ https:// edudoc.ch/record/25519/files/Gesamtsprachenkonzept.pdf?version=1> (22 October, 2018).

Ushioda, E. (2008). Motivation and good language learners. In C. Griffiths (Ed.), Lessons from good language learners (pp. 19-34). Cambridge: CUP. https://doi.org/10.1017/CBO9780511497667.004

Ushioda, E. (2009). A person-in-context relational view of emergent motivation, self and identity. In D. Zoltán, \& E. Ushioda (Eds.), Motivation, language identity and the L2 self (pp. 215-228). Bristol, UK: Multilingual Matters. https://doi.org/10.21832/9781847691293-012

Ushioda, E. (2013). Motivation and ELT: Global issues and local concerns. In E. Ushioda (Ed.), International perspectives on motivation: Language learning and professional challenges (pp. 1-17). Houndmills, UK: Palgrave Macmillan.

Ushioda, E. (2014). Context and complex dynamic systems theory. In Z. Dörnyei, P.D. MacIntyre, \& A. Henry (Eds.), Motivational dynamics in language learning (pp. 47-54). Bristol, UK: Multilingual Matters. https://doi.org/10.21832/9781783092574-008

Yun, Y. (2005). Factors explaining EFL learners' performance in a timed essay writing test: A structural equation modeling approach (Unpublished doctoral dissertation). Urbana, IL: University of Illinois at Urbana-Champaign.

Vanhove, J. (2013). The critical period hypothesis in second language acquisition: A statistical critique and a reanalysis. Plos One, 8(7), e69172. https://doi.org/10.1371/journal.pone.0069172

Vanhove, J. (2015, 16 October). The problem with cutting up continuous variables and what to do when things aren't linear [Blog post]. Retrieved from $<$ http://janhove.github.io /analysis/2015/10/16/nonlinear-relationships>

Verspoor, M.H., de Bot, K., \& Lowie, W. (Eds.). (2015). A dynamic approach to second language development: Methods and techniques. Amsterdam, Netherlands: John Benjamins.

Vesterbacka, S. (1991). Elever i Språkbadskola, Social Bakgrund och Tidig Språkutveckling [Summary, children in immersion programme, home background and early language development: Issues and strategies]. Newbury Park, CA: Sage.

Wesche, M., Toews-Janzen, M., \& MacFarlane, A. (1996). Comparative outcomes and impacts of early, middle and late entry French immersion options: Review of recent research and annotated bibliography. Toronto, Canada: OISE/UT Press.

Williams, M., Burden, R. L., \& Lanvers, U. (2002). French is the language of love and stuff: Student perceptions of issues related to motivation in learning a foreign language. British Educational Research Journal, 28(4), 503-528. https://doi.org/10.1080/0141192022000005805 


\section{Address for correspondence}

Simone E. Pfenninger

University of Salzburg

Department of English and American Studies

Erzabt-Klotz-Straße 1

5020 SALZBURG

Austria

simone.pfenninger@sbg.ac.at

\section{Biographical notes}

Simone E. Pfenninger is Associate Professor at the English Department of the University of Salzburg (Erzabt-Klotz-Strasse 1, 5020 Salzburg). Her principal research areas are multilingualism, psycholinguistics and individual differences (e.g. the age factor) in SLA, especially in regard to quantitative approaches and statistical methods and techniques for language application in education. She is the co-author of Beyond Age Effects in Instructional L2 Learning: Revisiting the Age Factor (2017), the co-editor of the Second Language Acquisition book series for Multilingual Matters, and the recipient of the Mercator Award 2015 and the Conrad Ferdinand Meyer Prize 2018 for outstanding research.

David Singleton is a Fellow Emeritus at Trinity College Dublin and holds professorships at the University of Pannonia (Egyetem utca 10, 8200 Veszprém) and the State University of Applied Sciences, Konin. His research publications focus on cross-linguistic influence, the lexicon, the age factor and multilingualism. He is the co-author of Key Topics in Second Language Acquisition (2014) and of Beyond Age Effects in Instructional L2 Learning: Revisiting the Age Factor (2017) and is co-editor of the Multilingual Matters SLA book series. In 2015 he received the EUROSLA Distinguished Scholar Award and in 2017 Honorary Membership of AILA. 